\title{
The Inscription of Fundamental Human Rights and the Liberation of the Igbo Woman from Customary and Administrative Burdens
}

\author{
Florence O. Orabueze \& Ifeyinwa Ogbazi* \\ http://dx.doi.org/10.4314/ujah.v14i2.1
}

\section{Abstract}

There is no doubt that the International Bill of Rights and other international legal instruments have sought to truly liberate every human being by the recognition of the equality and inalienable rights of all persons on the face of the earth as the foundation for peace, justice and freedom. In order to ensure that these rights are enjoyed by all, without exception, state-parties have been enjoined to domesticate the fundamental human rights and to further abrogate existing laws, including customary laws and practices, which constitute impediments to the full enjoyment of these rights by everybody. The Constitution of the Federal Republic of Nigeria, 1999, just as others before it, has incorporated these rights in its chapter four. The thrust of this research, therefore, is to critically examine three provisions of the grund norm - the right to the dignity of the human person, the right to freedom from discrimination and the right to the acquisition and ownership of property - as they concern the liberation of the Igbo woman. This is aimed at determining whether these constitutional provisions have really liberated her from customary practices that degrade, marginalize and disinherit her - whether as a widow, as a childless woman, as an unmarried woman and as an illegitimate daughter. It also questions whether her constitutional guaranteed rights have 
been abrogated through administrative actions and the struggle going on to liberate her.

\section{Introduction}

The Igbo ethnic group occupies the eastern part of Nigeria, and it comprises five states - Abia, Anambra, Ebonyi, Enugu and Imo. It is presumed to be the third largest ethnic group in Nigeria, out of more than two hundred and fifty groups that make up the country. Igbo language is the mother tongue of Igbo people. Pre-colonial Igboland operated a republican society, which was guided by customary law, which has been defined as 'Law consisting of customs that are accepted as legal requirements or obligatory rules of conduct; practices and beliefs that are so vital and intrinsic a part of a social and economic system that they are treated as if they were laws'. (Garner, 2009:443). The legal jurist, Lon L. Fuller explains further that 'A custom is not declared or enacted, but grows or develops through time. The date when it first came into full effect can usually be assumed only within the broad limits' (cited in Garner, 2009:443). Most of these laws, therefore, are buried in the minds of the people, particularly the elders, who are their custodians, and they evoke them, whenever the need arises. However, some of these customs, which are repugnant to natural justice, have given way before the forces of colonialism, Christian evangelization, education and enacted legislation. Oguejiofor (2009:v) observes:

There are, no doubt, many aspects of cultures that go against the core principles of the Gospel. Killing of twins, banishing of the leprous and those afflicted with small pox, non-burial of those who died of liver problems leading to swollen bellies are all practices that were common in Igbo culture but have now been definitely abandoned. 
These traditional observances as described above have their justification in this narration, 'That the sickness was an abomination to the earth, and so the victim could not be buried in her bowels' (Achebe, 1958:13). This customary law has a general application, and there are no exceptions - men and women, young and old, poor and rich, ordinary citizen and titled people - to its enforcement, because the Igbo believe that the land is sacred and the source of fertility and it will be polluted, when such corpses are buried in it. The universality of these customary laws is seen when the narrator recalls its application to Chief Eke's uncle, who died of elephantiasis of the scrotum:

A dead man is a dead man and if a man with what you call the evil disease must die, he may as well die early and save his friends,... his fate would still be the same; he would be thrown into the evil forest (Umeasiegbu, 1997:25).

However, this research intends to explore discriminatory practices that arise from surviving customary and administrative practices of public officers, which are harmful, degrading and oppressive to women. These practices exist in spite of women's legally guaranteed rights as inscribed in the constitution, international and regional conventions, declarations instruments and statutes, which are adopted and ratified by Nigeria as part of its international obligations. Some of the discriminatory practices not mentioned by Oguejiofor, which had fizzled out before the forces of development, include wife-inheritance or levirate marriage, child-betrothal and female genital mutilation, and a host of others. However, there are still other die-hard customs still in operation, which discriminate against women and marginalize them and ensure that they are not fully liberated. The Igbo woman, like her 
Ugandan sister, shares the same burden in the twenty-first century, because:

From the moment she takes her first steps, she will be regarded as inherently inferior to her brother. She will continually be battling against prejudicial attitudes and unfair work practices in a culture that places little or no value on her contribution to society .... More often than not, she is regarded more as a productive piece of property than as a person toiling long hours only for her husband to be paid (Burne and Davis, 1995: 83).

The Igbo woman, whether a daughter, a wife or a mother, is enveloped by discriminatory customary practices, which strip her of her personhood and property rights. Critics of these traditions have not been silenced in the face of the smoldering embers of these degrading traditions and administrative actions or inactions. Ohia (2011) identifies the nature and scope of gender inequity and gender stereotyping that make it impossible for women to take part in governance in Nigeria. She goes further to suggest the roles women can play in minimizing their exclusion from governance in the twenty-first century. Okeke also, examines the discriminatory widowhood practices as one of the harmful traditional practices that have stubbornly survived legislation, Christian evangelization and developments in science and technology. She recommends that women should do away with such obnoxious customs through the processes of enculturation and empowerment (2009). Besides, Agbasiere focuses on the Ibi community to explore the Igbo cultural heritage as well as the ideas and expectations of the culture from her. She also unmasks women's voicelessness and silence as a resu0lt of the tradition. Recently, Akachi T. Ezeigbo's discourse x-rays the gender-imbalance and gender-based discrimination the African 
woman is continually subjected to. She recommends a womancentered theory and strategy which she calls snail-sense feminism or womanism to be adopted by the women in the face of these debilitating and harmful practices that traumatize them.

But it is not only the women that are at the vanguard of the struggle to liberate them from all forms of discriminatory practices. There are also men who are sympathetic to their cause, and they work in tandem with the women for their liberation. For instance, Ezejiofor beams his critical lenses on the inhuman customary rituals and practices in Nigeria, which reduce widows to the position of subhumans. He further draws the attention of the reading public to the violations of the widows' rights as a result of such traditional practices.

There is no doubt, therefore, that critics have drawn attention to the exclusion of women as the 'other' in their various patriarchal and hegemonic societies because of customary and administrative practices. However, none of them has exclusively atomized the burden of Igbo women within the framework of international, regional and municipal legislation. This thrust of this study, therefore, is to beam the critical searchlight on discriminatory customary and administrative practices that divest the Igbo women of their constitutionally guaranteed rights, which derive their validity from international law. In Sagay's opinion, 'So important are human rights that the human rights of the individual are now recognized under international law' (1988: 170).

For the proper elucidation of this task, the researchers will appropriate primary and secondary methods of data collection. The primary data collection involves a field work through oral interviews of elders, who are the custodians of Igbo customary law. But for the purposes of confidentiality and identity, their names would not be mentioned. The 
secondary method of data collection involves the collation and analysis of material from the library.

\section{Provisions of Relevant Statutes on Fundamental Human Rights and Freedoms}

From time immemorial, human beings have tried to avoid the Hobbesian state of nature, where the weak are crushed by the strong. Therefore, the classical Greek and Roman philosophers had articulated the principles of fundamental rights or natural justice as part of natural law in their treatise. They believed that natural law and natural justice are anterior and superior to positive or man-made law. In his eulogy of natural law, the Greek orator and rhetorician states, 'It is for universal application, unchangeable and everlasting .... It is a sin to try to alter this law, nor is it allowable to try to repeal any part of it, and it is impossible to abolish it entirely' (Cicero cited in Malemi, 2012: 147). In order to forestall the anarchical situation, which caused humanity millions of lives and untold sorrow, because of the First and Second World Wars, the preamble to the Charter of the United Nations 'reaffirms faith in fundamental human rights, in the dignity and worth of the human person, in the equal rights of men and women'. From 1945 in San Francisco when the five founding members Britain, France, United States of America, China and Russia of the United Nations Organization adopted and ratified this charter, it has helped in the maintenance of world peace and security. In order to achieve these noble objectives, it has persuaded almost all the countries on the face of the earth to adopt, ratify and domesticate its International Bill of Rights, which comprises - Universal Declaration of Human Rights(1948), International Covenant on Civil and Political Rights(1966) and International Covenant on Economic, Social and Cultural Rights(1966). 
The Universal Declaration of Human Rights, for example, recognizes the fact that 'All human beings are born free and equal in dignity and rights' (Article 1). It goes on to emphasize the universality of the application of the rights and freedoms it embodies. This provision is also reiterated in the two covenants that make up the bill of rights. As far back as 1948, the declaration provides the right to freedom from discrimination, when it states, 'Everyone is entitled to the rights and freedoms set forth in this Declaration, without distinction of any kind, such as race, colour, sex, language, religion, political or other opinion, national or social origin, property, birth or other status (Article 2). In furtherance of ensuring the enjoyment of these rights by women, the United Nations adopted and ratified Convention on the Elimination of all Forms of Discrimination Against Women (CEDAW). It enshrines this right in it and also defines what constitute discrimination as:

....any distinction, exclusion or restriction made on the basis of sex which has the effect or purpose of impairing or nullifying the recognition, enjoyment or exercise by women, irrespective of their marital status, on a basis of equality of men and women, of human rights and fundamental freedoms in the political, economic, social, cultural, civil or any other field (Article 1).

The same declaration also provides that 'No one shall be subjected to torture or to cruel, inhuman or degrading treatment or punishment' (1948 Article 5). This same right to the dignity of the human person is also recognized in Article 7 of the International Covenant on Civil and Political Rights. In order to ensure that women are not victims of acts of violence, the General Assembly of the United Nations in its Resolution 
48/104 of 1993 made a proclamation, Declaration on the Elimination of Violence Against Women (DEVAW). The declaration defines 'violence against women' to mean 'any act of gender-based violence that results in, or is likely to result in, physical, sexual or psychological harm or suffering to women, including threats to such acts, coercion or arbitrary deprivation of liberty, whether occurring in public or private life' (1993 Article 1). The scope of this very law is wider that the others, as it states that acts of violence against women also encompasses female genital mutilation, trafficking in women, and violence related to exploitation.

In addition to the above provisions, the international community tries to ensure the right to acquisition and ownership of property by individual, and that such property is not confiscated by the state or other persons without prompt and adequate compensation. The Universal Declaration of Human Rights provides, 'Everyone has the right to own property alone as well as in association with others' (Article 17 (1)), and in 17 (2), it states further, 'No one shall be arbitrarily deprived of his property'.

International law has also sought to protect the fundamental rights and freedoms of women before, during and after marriage. The declaration of 1948 in its Article 16 (1) prohibits child-marriage; 16(2) prohibits forced marriage, and in 23 (4) ensures the equality of rights and responsibilities of spouses during marriage and at its dissolution. The United Nations reinforces its position on the nullity of marriage of minors, when it adopted and ratified Convention on Consent to Marriage, Minimum Age for Marriage and Registration of Marriage.

Apart from the protection of women, the United Nations is also desirous in guaranteeing the rights of children, as another group of vulnerable members of the society. Article 25 (2) of the Universal Declaration of Human Rights 
categorically states, "All children, whether born in or out of wedlock, shall enjoy the same social protection', and $C E D A W$ enjoins state-parties to recognize that both parents have equal rights with regards to the nationality of their children (Article 9 (2)). Its Article 16 (1) (d) gives both parents equal rights on matters relating to their children, and declares in 16 (2), 'The betrothal and marriage of a child shall have no legal effect'. Not yet satisfied with the protection of the rights of the child, the United Nations adopted and ratified Convention on the Rights of the Child in 1990. Its Article 1 defines a child to mean 'every human being below the age of eighteen years unless under the law applicable to the child, majority is attained earlier'. Article 2 of the convention enjoins stateparties to ensure that the child enjoys all the rights set forth in it without any discrimination whatsoever, irrespective of his or her parent's or legal guardian's race, colour, sex, language, religion, political or other opinion, national, ethnic or social origin, property, disability, birth or other status.

International law does not provide these rights and freedoms to decorate the statutes; they are intended to be incorporated or domesticated as part of each country's municipal law, so the rights and freedoms can be enjoyed at the grassroots level, and their abridgement to be enforced in national courts. Therefore, International Covenant on Civil and Political Rights enjoins state-parties to take measures necessary for the adoption of 'such laws or other measures as may be necessary to give effect to the rights recognized in the present Covenant' (Article 2 (2)). CEDAW also calls on states to ensure that appropriate measures are taken to modify the social and cultural patterns of conduct of men and women with a 'view of achieving the elimination of prejudices and customary and other practices' (Article 5 (a)) that inferiorize and/or stereotype the roles of men and women. A state-party 
that fails to set up such measures and women are subjected to violence in its territory 'should not invoke any custom, tradition or religious consideration to avoid its obligation' (Article 1 of $D E V A W$ ). And apart from the domestication of these international laws into national constitutions, and the abrogation of enacted laws and customary practices that negate the principles of natural justice and fundamental human rights and freedoms, International Covenant on Civil and Political Rights empowers the states to set up judicial, administrative and legislative authorities to determine the claim of an aggrieved person who applies to any of them for remedy. It further provides that the state cannot depend on the defence that the "violation has been committed by persons acting in an official capacity' (Article 2 (3) (a) ).

In addition to the provisions of international law, fundamental rights and freedoms are also embodied at the regional level in African Charter on Human and Peoples' Rights. Interestingly, some of the provisions of this charter which are applicable to the protection of women appear contradictory. Its Article 18(3) exhorts state-members of African Union to ensure the elimination of every form of discrimination against women and children in accordance with stipulated international declarations and covenants. However, its earlier provision in Article 17(3) states, "The promotion and protection of moral and traditional values recognized by the community shall be the duty of the state. With due respect, it is submitted that this provision should be expunged from the Charter as it is against the spirit and intendment of Article 18 (3) of the charter and the provisions of international law that guaranteed the rights of women. In effect, what the Charter is saying is that whether the moral and traditional values are repugnant to natural justice or not, they should be protected by the state. It seems to me that what the Charter is advocating is that such customary practices, like the killing of twins, 
degrading widowhood practices, the outcast system, slavery, human sacrifices and a host of others, because they are recognized by the community, the state should protect them. After all, in the past, they were recognized by the communities as being moral.

Besides, Igboland is an integral part of Nigeria, and Nigeria, over the years, operates a constitution that embodies the fundamental rights and freedoms in its provisions. Chapter IV of the Constitution of the Federal Republic of Nigeria, 1999(as amended), which is in use today, devotes fourteen sections to these natural rights, which are in tandem with the provisions of the international laws discussed earlier in the work. The particular provisions of the constitution - right to the dignity of the human person, right to freedom from discrimination and right to acquisition and ownership of property anywhere in Nigeria - will be quoted verbatim, for it is against their backdrop that customary and administrative practices, which violate the Igbo women's guaranteed rights will be examined.

The Constitution provides in its section 34 for the guaranteed right of the dignity of the human person. Its subsection (a) specifically states, 'No person shall be subjected to torture or to inhuman and degrading treatment'.

Its section 42 guarantees the right to freedom from discrimination, and particularly states in subsection (1), 'A citizen of Nigeria of a particular community, ethnic group, place of origin, sex, religion or political opinion shall not, by reason only that he is such a person'-

(a) be subjected either expressly by, or in the practical application of, any law in force in Nigeria or any executive, administrative action of government, to disabilities or restrictions to which citizens of Nigeria of other communities, ethnic groups, places of origin, 
sex, religions, or political opinions are not made subject.

Section 42 (2) - No citizen of Nigeria shall be subjected to any disability or deprivation merely by reason of the circumstances of his birth.

Moreover, section 43 states, 'Subject to the provision of this constitution, every citizen of Nigeria shall have the right to acquire and own immovable property anywhere in Nigeria'. It further gives special jurisdiction to the high court in section 46 (1) because, "Any person who alleges that any of the provisions of this chapter has been, is being, or likely to be contravened in any state in relation to him may apply to high court in the State for redress'. In order to forestall poverty as a ground for accommodating abuses of an individual's human rights and freedoms, the same constitution provides for financial and legal aid for indigent citizens to procure a legal practitioner to prosecute his or her case in a high court in section 46 (4) (b) (ii).

Having surveyed the constitutionally guaranteed rights, one wonders why some of the harmful customary practices and administrative actions of persons in authorities, which the constitution itself $a b$ initio voids in section 1(3), where it states clearly, 'If any other law is inconsistent with the provisions of this constitution, this constitution shall prevail, and that other law shall to the extent of the inconsistency be void'. This is the supremacy of the constitution in every sovereign state 'against which inconsistent enactments and conducts are null and void. It is the grand law and authority base of the country' (Malemi, 2012: 62) Justice NnaemekaAgu, retired Justice of the Supreme Court of Nigeria, in Imonikhe v A.G. Federation declares that "A constitution is the organic law, a system or body of fundamental principles according to which a nation, a state, or body or organization is 
constituted and governed' (1992:166). The constitutionality of these fundamental rights and freedoms is reaffirmed by Justice Idigbe's statement that 'Since these rights derive their guarantee from the constitution, it follows, therefore, that provisions of the ordinary laws of the land which conflict with, or are repugnant to them, must at least to the extent of the conflict or repugnancy be void' (1982:41). Furthermore, Justice Kayode Eso, another justice of the Supreme Court, underscores the essentiality of these rights when he states, 'But what is the nature of fundamental right? It is a right which stands above the ordinary laws of the land and which in fact is antecedent to the political society itself. It is a primary condition to civilized existence' (1985:211).

For the enforcement of fundamental rights in Nigeria, the constitution gives original jurisdiction to State High Courts and Federal High Courts. The enormous role of the court in the protection of fundamental rights and freedoms cannot be overstressed. According to Justice Kayode Eso:

There is no justification for the existence of the judiciary except in its existence for the defence of the citizen, for the citizen to put his views across with all potency, for him to vent his feelings, and his success in the public, for him to feel and breathe the air of freedom around him (cited in Agbede, 1993: 30).

In another jurisdiction, the same view is expressed by Justice Hugo Black of the United States Supreme Court in Chambers $v$ Florida, where he observes, 'Courts stand... as heavens of refuge for those who might otherwise suffer because they are helpless, weak, outnumbered, or are victims of prejudice and public excitement' (1960:238). 


\section{Igbo Discriminatory Customary Laws and Practices}

Despite the existence of this plethora of laws - international, regional and municipal - which guarantee the rights of every citizen, particularly women and children, there are still diehard customs that survive the hammer of enacted laws. These customs are gender-based and injurious to the vulnerable groups: women and the girl-child. It is to be recalled that male and female writers of Igbo extraction - Chinua Achebe, Flora Nwapa, Buchi Emecheta, Ifeoma Okoye, Akachi AdimoraEzeigbo - to mention only these five, have drawn attention to some of these harmful customary practices. Some of them are the osu caste system, widowhood practices, polygamy, wifeinheritance, human sacrifices, slavery and slave trade, female genital mutilation, disinheritance of women, child-betrothal, killing of twins ignominious treatment of barren women and illegitimate children. All these traditional practices constitute acts of violence and indignity to their victims. However, with developments, some of these customs have either been buried or their effects whittled down considerably. Gender-based widowhood practices, disinheritance of women and abuses of girls born out of wedlock, are still alive and thriving in Igboland.

The right to the dignity of the human person is violated when a married man dies; his widow or widows are subjected to torture, cruel and inhuman treatment by the husband's family, particularly the womenfolk. The Igbo custom expects the widow to mourn the husband for one year, and within that one year, she is expected not to take part in social activities. Immediately her husband's corpse is lowered into the grave, the women lead her into the house, where her head is scraped clean of any strand of hair like a criminal in prison custody. She changes into black mourning dress which she will wear for one year. This can only happen if the husband's relations do not suspect her of killing him. If they do, she can be forced to 
swear an oath or drink the water used in washing the corpse in order to prove her innocence. If she fails in any of the duties the custom demands from her, her action is labeled abominable and sanctions will be placed on her. This discriminatory attitude to women is not applicable to widowers. The Igbo widowhood practice exempts them from its violence because:

If a wife dies, the man is confined to the house for a month, but the man may break the rules. It cannot be an abomination if he breaks the rule, but people can talk. There are no sanctions. Maybe sanction by shunning. It becomes an abomination if he impregnates another woman during the mourning period (Ewelukwa, 2002: 439).

With all due respect, Ewelukwa's statement is partially true, but I must submit that if the man has in his possession several women as wives, the custom cannot stop him from sleeping and putting them in the family way, simply because he is mourning one of them, who had died. His assertion can only be obtainable in a truly Christian monogamous marriage.

The Igbo customary widowhood practices, like all customs, are unwritten and nobody knows who formulated them and when they commenced. But one thing that we are sure of is that women are its victim and its victimizers or enforcers. In Ogbu's The Moon Also Sets, like other novels that have dealt with the theme of widowhood, it is the womenfolk that enforce these discriminatory, degrading and cruel customs that torture the widow. The narrator says in this novel that the widow is kept in isolation, clean-shaven, dressed in ugly black, sat on a mat not less than two square feet on a bare floor with female relations in attendance. It is the same women, as their custom demands, when '... she displayed imaginary wares as market women poured scorn on her. She 
acted as both buyer and seller. She was compelled to talk to herself as part of the ritual' (15). From this narration, it is obvious that the women cannot be exempt from their own ordeal, in the name of custom.

It must be mentioned that some aspects of the widowhood practices, like the isolation of the widow, her outing in the market with imaginary wares, the compulsory wearing of black for mourning, are no longer in vogue. Their falling into disuse is not because of the constitutional rights and freedoms, but because of Christian evangelization in Igboland. The various Christian denominations persuasively '... re-direct the traditional hangovers' (Izunwa and Mgbemena, 2012: 122) of their members to discard some of these widowhood practices, because they are heathenish. For instance, the Church recommends white mourning clothes to be worn instead of black as the Igbo custom demands.

But the travail of the widow does not end with the burial of the husband. The indignity and discriminatory treatment she receives then is only a tip of the iceberg. If she has a grown up son or sons, they will protect their mother against further abuses. If she is young, she still has to go through the crushing mill of custom and greed of brothers-inlaw. In the past, one of her husband's brothers will inherit her. If she is lucky, she will take care of her and her children; if she is not, he will simply divest her and her young children of her husband's property, particularly houses, land and economic trees. If the deceased is young and still has interest in his family property, the widow will not be given her share, as she will be told that women, according into Igbo custom, do not take part in the sharing of land. Even if she has sons that are young, they will not be there when their uncles share the land. If the deceased has a testamentary document that leaves his property to his wife and children, it is not material to the brothers, who operate even outside the custom, to grab their 
late brother's property at the detriment of his nuclear family. The young widow, finding the world as a wilderness filled with thorns and brambles, is discouraged from going to court as a result of the sanctions, including ostracism, such a bold step will incur for her and her children from the late husband's family. Having been divested of her property right as guaranteed in the Constitution, afraid of the wrath of sanctions, she lives in grinding poverty to bring up her young children.

The Igbo woman, before she grows up to marry and to be widowed, goes through harrowing experiences in name of tradition. There may not be much difference between the soulless statement of Tsitsi Dangarembga's protagonist, who shocks the reader in her opening statement, 'I was not sorry when my brother died. Nor am I apologizing for my callousness, as you may define it, my lack of feeling' (1988:1) and what an Igbo girl feels when disinherited in her father's house. However, Tambudzi's statement in Nervous Conditions is understandable in a culture that prefers male-child to the femalechild, denies her right to Western education and condemns her to a life of drudgery, where her father remorselessly reminds her of her stereotypical role as, 'Can you cook books and feed them your husband? Stay at home with your mother. Learn to cook and clean. Grow vegetables' (15) while her brother goes to school. The Igbo girl in her house has gone beyond such gendered role, because she can afford to take the benefits of Western education. But she is still over-burdened with discriminatory custom that denies her acquisition and ownership of immovable property in her father's house. In Igboland, female children do not have any share of land in their father's house, but in their husbands, and the share is not given to them directly but through their male children. Therefore, she will not have any land, if she is unmarried, or married but childless or has only female 
children. The constitution that guarantees every person's right to ownership of property anywhere in Nigeria has rendered this discriminatory custom that disinherit Igbo female children null and void. But this customary practice remains operational even today as can be seen from the interviews I conducted during the time of this research.

It is obvious that gender-discriminatory custom that disinherit women from acquisition and ownership of land in their fathers' families has not been whittled down by education, the constitutional provisions and Christianity. This is because it has permeated the mindset of the people - men and women, educated and uneducated, young and old, married and single - for they condone it and are not in a hurry to do away with it. And those who are the victims of its operation have not challenged it in court, and if they have, the court has not made a pronouncement on it for it to become a case law. In fact, this custom is regarded as a notorious custom, that is, a custom the court has taken judicial notice of. In 2012, One of us had an interview with a very senior lawyer, who has been in legal practice for four decades in Enugu. This interview was necessitated when he gave her his testamentary disposition to proof-read for him. Out of four houses he owned in Enugu, he gave two to his grandson, whose father had died. The grandson also had a younger sister, whom he left with nothing except chose in action, which he also gave to his grandson. She asked him why he left nothing for the little girl, leaving her to an unknown fate, despite the constitutional provision. He told her bluntly that she should depend on her brother to provide for her; he did not want the ownership of the property to leave his family, when she is married, and that his action was dictated by Igbo custom on inheritance.

Equally, on $6^{\text {th }}$ January, 2013, we took part in the sharing of the property of a relation, who died intestate. The deceased had five children - three men and two women. The 
immovable property to be shared consisted of fifty shops in a highly developed market in Onitsha. The daughters had before the meeting raised the issue of their interests in the sharing of the property, because their late father promised to buy things for them during their wedding as Igbo custom specifies, which is called idu uno. However, he did not do that before his death. Out of almost thirty people that were present at the event, we were the only ones who raised objections, when it was decided according to Igbo custom, that the two women could not get a share of the landed property. It was in addition decided that the rent collected from all the stalls for one year should be shared between the two women, but their permanent ownership resided with the three men, who were given various shares of the stalls. When we reminded them that this custom violated their constitutional rights in section 43, the elders told us that the decision was based on Igbo custom on inheritance. However, the women-victims of these laws which had been over-ridden by the constitution and their husbands were contented with what they were given.

It is also a trite statement that children, particularly girls, born out of wedlock, are discriminated against and subjected to torture, cruel and inhuman treatment that constitute physical, sexual and psychological violence on them. This is despite the constitutional provision in section 42 (2), which states, 'No citizen of Nigeria shall be subjected to any disability or deprivation merely by reason of the circumstances of his birth'. Generally, both boys and girls born out of wedlock suffer tremendously, whether they are with their maternal uncles or stepfathers. For an illegitimate son who is unclaimed by the biological father will be bluntly told his status in the family, if he questions the reason for disinheriting him. For the illegitimate girl, already the custom has disinherited her and she is aware of that from childhood. 
However, her own case may take a more dangerous dimension, if she is unclaimed by the biological father, her maternal uncles and aunties reject her, and she follows the mother, to live with a step-father. The step-father usually discriminates against her, subject her to indignities, but worst of all, abuse her sexually and psychologically. Ama recollects the sexual ordeal she suffers that forces her into prostitution in Belgium in Chika Unigwe's 2012 LNG award-winning novel:

I am not your father. You hear that? I took in your mother and this is all the thanks I get. All the thanks I get for saving you from being a bastard. All the years I raised you, fed you, this is all the thanks I get. You know what happens to children without fathers? Children who are born at home? Father unknown? Ime mkpuke! I want you out of my house. I want you out. Tata. Today! As God is my witness, you shall leave my house today (2009: 148-149).

Some men may never allow the woman to bring her illegitimate child into his house. The Igbo society of today has partially solved the dilemma of teenage pregnancy, abortion, throwing babies into heaps of dustbin or bearing illegitimate children at home are discouraged by adoption of such children by childless couples. However, it has become a booming business.

\section{Violations of the Rights of Igbo Women by Administrative Authorities}

It is not only Igbo customary practices, which violate the fundamental rights and freedoms of Igbo women, but also administrative actions of persons in authorities, despite the fact they are guaranteed by the constitution and international law. For instance, Article 2 (3) (a) of International Covenant on Civil and Political Rights enjoins state-parties to ensure that 
victims of such violations get remedy "notwithstanding that the violation has been committed by persons acting in an official capacity'. This part of the covenant is not reflected in the Nigerian constitution, and this presumably is intended to give immunity to persons, who may violate other citizens' rights in the course of their duties. But the constitution provides 'compensation and official apology from the appropriate authority' (Article 35 (b)) to those who are unlawfully arrested and detained. The violation that is based on gender we are interested here is the refusal of police in allowing women to stand as surety for suspects in police custody. The constitution guarantees the equality of every citizen and none shall suffer any discrimination on whatever ground, including sex. The Police Act and Regulations in Section 27 (a) provides the conditions for bailing a suspect detained by the police. It further empowers the police officer in charge of a police station to release the suspects, if the offence is not serious, but:

... when the case appears to such officer to be of a serious nature, may release such a person upon his entering into a recognizance, with or without sureties, for a reasonable amount to appear before a magistrate at the day, time and place mentioned in the recognizance.

It is obvious that the constitution confers equality on all men and women, and the Police Act never specifies the sex of the surety. However, it is regrettable that the practice in the twenty-first century in Nigerian police stations is that administrative beauraucracy is used to bar women from standing as sureties to suspects, both male and female. Women have not gone to court to contend this discriminatory and preposterous practice, or if they have gone, the decisions have not been made a case law that everybody, including police men and women will take notice of its existence. 
Closely-related to this is the discriminatory action of Nigeria Immigration Service authorities. Part of its compulsory requirements before it issues an international passport to a minor, who is brought to their office by the mother, is that a written consent of his or her father must be brought and attached to the passport is the photograph of the father. With due respect, immigration service should take note that the liberation of women and their equality with the men are inscribed in the constitution and other enactments. Therefore, they should not be treated discriminatorily since they do not subject men who come with their children with the same demand to such indignity and cruel treatment. Ironically, the Igbo women are not the only victims of such reckless administrative actions of the police and immigration service. I presume that women have not contended the validity of such discriminatory actions for the court to pronounce them null and void like in Reed $v$ Reed. In this case, the United States Supreme Court declared Idaho State law, which gives fathers preference over mothers in the administration of their children's estate, as discriminatory, null and void. It further held that the Fourteenth Amendment of the Constitution of the United States on $28^{\text {th }}$ July, 1896, stated that rights of citizens could not be abridged and gave equality of enjoyment of rights to all the citizens (1971:71). It should be restated that if any Igbo or Nigeria woman, for that matter, takes this violation to court, there are legal backings to void the illegality. For instance, Universal Declaration of Human Rights gives equal rights to married couple during the continuance of the marriage and at its dissolution (Article 16 (1)). This right is reiterated in Article 23 (4) of International Covenant on Civil and Political Rights, Article 16 (1) (d) of Convention on the Elimination of all Forms of Discrimination Against Women, and the 'Preamble' to Convention on Consent to Marriage, Minimum Age for Marriage and Registration of Marriage. Also section 
42 of the constitution provides for the right to freedom from discrimination is also applicable. Though Nigeria Immigration Service authority may claim that it is taking such an action to forestall law-suits against it by aggrieved fathers, who may sue it for connivance in the illicit transfer of their children, who are minors abroad, they should be reminded that the action of its officers is not only one-sided but also lopsided as the men may also transfer their children without the consent of their wives. If they genuinely want to combat such an action, it should be of general application. In the course of their duty, they should bear in mind the obiter dictum of Justice Herring in Arthur Yates \& Pty Ltd v Vegetable Seeds Committee, where he states, 'It is not the English view of law that whatever that is officially done is law.... On the contrary, the principle of English law is that what is done officially must be done in accordance with the law (1945:116).

\section{The Struggle to Liberate the Igbo Women}

There is no doubt that Igbo customary law and practices as well as the administrative actions of persons in authorities infringe the fundamental rights and freedoms of the Igbo woman. The women are discriminated against, when they are subjected to indignity and violence in the name of widowhood practices. They are also subjected to discrimination through a tradition that disinherits them from the acquisition and ownership of property in their fathers' and husbands' houses. They are discriminated against, degraded and humiliated when they are born out of wedlock. Through actions of person in authorities that operate outside the ambits of enacted laws, they are discriminated and marginalized. It must be said that women have not taken advantage of constitutional and international law to seek redress. However, Christianity has done a lot to do away with the obnoxious and harmful 
customary laws, but nothing has been done about administrative actions that treat women as second class citizens in their own country.

Besides, the non-governmental organizations with their various umbrellas operating in the country also try to protect the rights of women. Some of them that are women-oriented try to sensitize women on their rights and help them in prosecuting cases of violations of their rights in court. But some of them fail in their duty to the citizenry, including women, when the overriding interest of their owners is procuring foreign donors to sponsor their taste for exotic cars, state-of-the-art building, frequent overseas travels and unimaginable fat bank accounts. They can do better than they are doing at present, if they can take their campaigns to the rural areas of Igboland, where such violations of rights are rampart.

Finally, we cannot rule out that the women should strive to liberate themselves from the burden of vicious customs and administrative practices. Fire and ashes come from the mind, and it depends on which of them the individual wants to rule his or her life. Either one chooses the fire of freedom or the ashes of servitude. Chinua Achebe's recollection of his mother's assertion of her right, which predates all the provisions that guaranteed rights, is revealing. According to his story in There Was A Country, his mother was one of the earliest Christian converts in Igboland. One day, she pulled down a branch from a kolanut tree in her compound and plucked out some kolanut pods. A man who was watching her reported her action to the men folk as an abomination to their custom. However, his mother insisted that her action was not an insult and a taboo to their custom. Because of her stoicism in defence of her right, they could not sanction her. As he concludes, 'There was pressure to punish my mother, though it did not go anywhere at the end' 
(2012:10). His mother's mind was made of fire, and she stood for her rights, even in those dark days when customary law and practices held sway. One should note that without the mind's determination to free itself, the inscription of fundamental rights and freedoms in statute books are like unlit logs of wood in a hearth.

\section{Conclusion}

It cannot be overstressed that the Igbo women's liberation has been inscribed in enacted laws, which void customary and administrative practices that degrade and dehumanize her. Some of the harmful traditions like child-bride, female circumcision and wife-inheritance, have been thrown into the trash-can of history due the influence of combined forces education, Christianity, legislation, etc. However, there are still others that survive the flux of time and development and the Igbo people still cling to them. It is submitted that some of these practices - widowhood practices, disinheritance of women and maltreatment of illegitimate daughters - constitute violations of their victim's fundamental rights and freedoms as enshrined in various statutes.

In addition, some administrative actions of some organs and agencies of government, like those of the police force and immigration service, derogate these rights and freedoms. Igbo women who are victims or are likely victims of these violations shy away from applying to a State High Court or Federal High Court for the enforcements of their rights. Indigence cannot preclude one from the prosecution of the case as the law established Legal Aid Council to provide legal practitioner to the victim or likely victims of such violations. Gender-based discriminatory treatment will never abate until the Nigerian court, probably the Supreme Court, makes a pronouncement on it that will make it a case law like the 
decision of the United States Supreme Court in Brown v Board of Education. This case over-ruled Plessy $v$ Ferguson that sanctioned racially segregated schools in the United States. The Supreme Court's judgment in Brown's case in 1954 is the foundation of desegregation of schools in the United States, and the bedrock of the enjoyment of fundamental rights and freedoms by non-white in the United States up until today.

Florence Orabueze is of the University of Nigeria, Nsukka while Ifeyinwa Ogbazi is of the Department of English Language and Literature, Nnamdi Azikiwe University, Awka

\section{References}

Achebe, Chinua. Things Fall Apart. London: Heinemann, 1958. Print.

There Was A Country. London: Penguin Group, 2012. Print.

Agbasiere, Joseph-Therese. Women in Igbo Life and Thought. New York: Routledge, 2000. Print.

Agbede, I.O. 'The Rule of Law and the Preservation of Individual Rights'. Individual Rights under the 1989 Constitution, NIALS. 1993. Print.

Burne, Simon and Wendy Davis (eds). In Defence of Women

Fighting for Equal Rights in Uganda, Let the Dawn

Come: Social Development: Looking Behind the

Clichés. London; Panos Publications Ltd, 1995. Print.

Dangarembga, Tsitsi. Nervous Conditions, Oxfordshire: The Women's Press Ltd, 1988. Print.

Ezeigbo, Akachi T. Snail- Sense Feminism: Building on an Indigenous Model. Monograph series of Faculty of Arts, University of Lagos. April 2012. Print.

Ewelukwa, Uchechukwu. 'Post-Colonialism, Gender, Customary Injustice: Widows in African Societies', Human Rights Quarterly 24.2 (2002): 424-487. Print. 
Ezejiofor, Austin Obinna. 'Patriarchy, Marriage and the Rights of Widows in Nigeria'. Unizik Journal of Arts and Humanities 12.1 (2011): 139 -157. Print.

Garner, Bryan (ed). Black's Law Dictionary. $9^{\text {th }}$ edition. Minnesota: Thomson Renters, 2009. Print.

Idigbe, Chukwunweike. 'Fundamental Rights Provisions of the Constitution'. Nigerian Judges Conference Papers, 1982. Print.

Izunwa, Maurice and Stanley Mgbemena. 'A Schematic Evaluation of the Impact of Heresies and Persecution in the Catholic Church: An Igbo Pragmatic Perspective'. Unizik Journal of Arts and Humanities 13.1 (2012): 100-125. Print.

Malemi, Ese. The Nigerian Constitutional Law with Fundamental Rights (Enforcement Procedure) Rules. $3^{\text {rd }}$ edition. Lagos: Princeton Publishing Co., 2012. Print.

Ogbu, Osi. The Moon Also Sets. Ibadan: Heinemann, 2007. Print.

Oguejiofor, Obi J. 'Forewords' in Cornelia C. Okeke's The Christian Pastoral Challenges of Widowhood Practices among The Igbo of Nigeria. Enugu: Victojo Production Services, 2009. Print.

Ohia, Nkiru. 'The Role of Women in Minimizing Gender Inequity in Governance'. Journal of Good Governance in Africa 2.1 (2011): 168-178. Print.

Okeke, Cornelia C. The Christian Pastoral Challenges of Widowhood Practices among the Igbo of Nigeria. Enugu: Victojo Production Services, 2009. Print.

Sagay, Itsejuwa. 'A Legacy of Posterity: The Works of the Supreme Court (1980-1988)'. Nigerian Law Publications. 1988. Print. 
Umeasiegbu, Rems N. Out of the House of Symbol. Enugu: Cecta (Nig.) Ltd., 1997. Print.

Unigwe, Chika. On Black Sisters' Street. London: Random House Group, 2009. Print.

\section{Statutes}

African Charter on Human and People's Rights, 1981. Print. Charter of the United Nations, 1948. Print.

Constitution of the Federal Republic of Nigeria, 1999. Print.

Convention on Consent to Marriage, Minimum Age for Marriage and Registration of Marriage, 1964. Print.

Convention on the Elimination of all Forms of Discrimination Against Women, 1981. Print.

Convention on the Rights of the Child, 1990. Print.

Declaration of the Elimination of Violence Against Women, 1993. Print.

International Covenant on Civil and Political Rights, 1966. Print.

International Covenant on Economic, Social and Cultural Rights, 1966. Print.

Police Act and Regulations, Cap P19, 1967. Print

Universal Declaration of Human Rights, 1948. Print.

\section{Cases}

Arthur Yates \& Co. Pty Ltd v Vegetable Seeds Committee (1945) 72 CLR 137 at 166. Print.

Brown v Board of Education (1954) 347 US 483. Print. Imonikhe v A.G. Bendel (1992) 6 NWLR pt 166 SC. Print. Ransome Kuti v A.G. Federation (1985). 2 NWLR pt. 6. p. 211 at 229-230. Print.

Reed $v$ Reed (1971) 404 US 71. Print. 